\title{
A produção do espaço urbano na cidade de Campinas
} 2000-2017

\author{
The production of urban space in the city of Campinas - 2000-2017
}

\section{La producción de espacio urbano en la ciudad de Campinas - 2000-} 2017

\author{
BARBUTTI, Márcio Rodrigo ${ }^{1}$ \\ BENFATTI, Denio Munia²
}

\begin{abstract}
${ }^{1}$ Programa de Pós-Graduação em Urbanismo, CEATEC - Centro de Ciências Exatas, Ambientais e de Tecnologias, Pontifícia Universidade Católica de Campinas, Campinas - SP, Brasil.barbutti_mr@yahoo.com.br ORCID: 0000-0002-9475-473X
\end{abstract}

${ }^{2}$ Pesquisador do Laboratório QUAPÁ, Faculdade de Arquitetura e Urbanismo, Universidade de São Paulo, São Paulo - SP, Brasil.dbenfatti@uol.com.br ORCID: 0000-0002-9468-2414 


\title{
Resumo
}

O artigo proposto decorre de uma dissertação de mestrado e analisa a expansão urbana recente do município de Campinas a partir do levantamento dos loteamentos aprovados no período 2000-2017. Esta base de dados nos permite compreender as diferentes configurações da expansão e transformação urbana da cidade nestes últimos vinte anos. Como nem todos os empreendimentos aprovados foram efetivamente realizados, a pesquisa contrapõe as informações cadastrais com as transformações verificadas nas imagens da plataforma Google Earth no período considerado. A acessibilidade, neste trabalho, é tomada como um elemento que influi fortemente nos valores imobiliários. Em contrapartida, seus diferentes níveis de serviço estariam criando áreas visivelmente segregadas no processo recente de expansão urbana. Por um lado, o sistema viário principal, as rodovias e as principais avenidas de circulação automobilística e, por outro, as áreas mais cativas do transporte público estão sendo determinantes na localização diferenciada dos novos loteamentos. No caso específico, além da influência dessas infraestruturas, a legislação urbanística local tem contribuído para induzir transformações significativas na forma urbana e na construção da cidade, principalmente de suas bordas mais recentes.

Palavras-chave: Forma Urbana; Campinas/SP; Urbanização Contemporânea; Tipos de Loteamentos

\begin{abstract}
The proposed article is based on a master's thesis and analyzes the recent urban expansion of the municipality of Campinas, based on the survey of approved lots in the period 2000-2017. This database allows us to understand the different configurations of the expansion and urban transformation of the city in the last twenty years. As not all the approved projects were effectively carried out, the research contrasts the cadastral information with the transformations verified in the images of the Google Earth platform in the considered period. Accessibility, in this work, is taken as an element that strongly influences real estate values. In contrast, their different service levels would be creating areas visibly segregated in the recent process of urban expansion. On the one hand, the main road system, highways and main avenues of automobile circulation and, on the other hand, the more captive areas of public transport are being decisive in the differentiated location of the new allotments. In the specific case, besides the influence of these infrastructures, the local urban legislation has contributed to induce significant transformations in the urban form and in the construction of the city, mainly of its more recent borders.
\end{abstract}

Keywords: Urban Form; Campinas/SP; Contemporary Urbanization; Types of Allotments

\section{Resumen}

El artículo propuesto deriva de una disertación de maestría, y analiza la reciente expansión urbana de la ciudad de Campinas a partir de levantamiento de los loteamientos aprobados en el período 20002017. Esta base de datos nos permite comprender las diferentes configuraciones de la expansión y transformación urbana de la ciudad en estos últimos veinte años. Como no todos los proyectos aprobados, fueron efectivamente realizados, la investigación contrasta la información del registro catastral con las transformaciones verificadas en las imágenes de la plataforma Google Earth en el período considerado. La accesibilidad, en este trabajo, se toma como un elemento que influye fuertemente en los valores inmobiliarios. En contrapartida, sus diferentes niveles de servicio estarían creando áreas visiblemente segregadas en el reciente proceso de expansión urbana. Por un lado, el sistema vial principal, las autopistas y las principales vías de circulación de automóviles y, por otro lado, las áreas más dependientes del transporte público son factores determinantes en la diferente ubicación de los nuevos loteamientos. En el caso específico, además de la influencia de estas infraestructuras, la legislación urbana local ha contribuido a inducir transformaciones significativas en la forma urbana y en la construcción de la ciudad, principalmente en sus fronteras más recientes.

Palabras clave: Forma urbana; Campinas / SP; Urbanización contemporánea; Tipos de loteamientos 


\section{Introdução}

O presente artigo traz para discussão parte de uma pesquisa de mestrado sobre a expansão urbana recente do município de Campinas, em uma leitura da espacialidade urbana contemporânea apoiada nos loteamentos aprovados entre os anos de 2000 e 2017. Trata-se, é bom lembrar, de um levantamento restrito à expansão urbana da cidade legal, daquela que é aprovada e chancelada pela administração pública. É importante ressaltar que o recorte temporal teve como base a disponibilidade de dados, quando, a partir de 2000, a PMC passou a organizar e sistematizar as informações em meio digital dos pedidos de aprovação de loteamentos, forma esta que possibilitou a reunião de dados e, assim, a definição do universo de pesquisa.

A identificação dos diversos loteamentos, seus diferentes tipos e sua apresentação em mapas tornou factível a espacialização destes na mancha urbana da cidade, permitindo identificar as áreas onde há maior concentração de loteamentos na cidade e também diferenciar a predominância de loteamentos fechados na região nordeste e de conjuntos habitacionais de interesse social nas regiões sudoeste e noroeste. Em uma análise mais específica das formas de expansão associada aos principais tipos de agrupamentos, tanto os loteamentos fechados da região nordeste como os conjuntos habitacionais multifamiliares das regiões sudoeste e noroeste, foi possível avaliar, como tendência, que a urbanização destas últimas décadas se fez através de glebas significativamente maiores que os loteamentos de décadas anteriores, como também se organizam, predominantemente, de forma condominial. A seguir apresentamos a pesquisa propriamente dita, ou seja, o universo de empreendimentos aprovados no município de Campinas no período 2000-2017.

\section{Expansão urbana e os empreendimentos aprovados entre 2000 e 2017}

O estudo propõe um recorte temporal sobre a expansão urbana de Campinas a partir do levantamento dos loteamentos aprovados no período de 2000 a 2017. Importa salientar que o tecido urbano de Campinas, formado no período mais recente de sua história, na segunda metade do século XX, não se mostra como um tecido coeso e contínuo, mas, ao contrário, desde os anos 1950 as novas urbanizações caracterizaram-se pela descontinuidade e pelos vazios urbanos perceptíveis até hoje.

Entretanto, ao longo dos últimos trinta anos, foram produzidas importantes modificações na organização espacial daquilo que a literatura denomina e caracteriza como metrópole moderna (SOJA, 2008, p. 335). Mais do que isso, as conceituações trazem como primeiro pressuposto a questão da escala. O neologismo megalópole e seus desdobramentos, presentes em um número significativo de autores - Gottman, Soja, Castells, Ascher, Choay, Secchi -, refere-se tanto ao enorme contingente populacional como a sua configuração espacial descontínua, alargada, fragmentada, pós-urbana, policêntrica etc., portanto, maiores e mais complexas em sua estrutura socioespacial que as metrópoles industriais do século XX. Entretanto, este trabalho coloca-se na perspectiva de esclarecer quais características das transformações estabelecidas para as megacidades poderiam também referenciar as análises de metrópoles secundárias e cidades de porte médio.

As transformações a que nos referimos acima teriam induzido modificações significativas nas condições urbanas, as quais, segundo nossa perspectiva, variam significativamente de cidade para cidade e mais ainda quando se considera diferentes escalas e diferentes contextos socioeconômicos. As causas dessas transformações têm sido genericamente imputadas aos processos de reestruturação urbana. Entretanto, segundo Soja (2008, p. 17), este consenso sobre as transformações urbanas das últimas décadas termina aqui. Novos termos e conceitos para descrever esta reconfiguração espacial e suas especificidades têm desencadeado debates acalorados acerca da melhor forma de captar as características mais importantes dessa reconfiguração espacial (SOJA, 2008, p. 335). Portanto, neste trabalho, procuramos nos manter dentro dessas grandes questões teórico-metodológicas (PORTAS; DOMINGUES; CABRAL, 2011, p. 19), buscando, ao mesmo tempo, enfatizar a importância de entender esses processos e suas diferenças em realidades sociais e espaciais distintas, ou seja, como esses novos processos de urbanização e seus efeitos concretos na vida diária do cidadão se expressam em contextos e territorialidades específicas. No caso, trata-se do entorno construído da 
cidade de Campinas, das formações urbanas emergentes e largamente majoritárias do ponto de vista de extensão territorial. $O$ trabalho toma como objeto de pesquisa os novos loteamentos aprovados pela prefeitura municipal nessas duas últimas décadas.

No recorte espacial proposto encontramos, de forma predominante, dois tipos principais de empreendimentos: aqueles voltados às classes de renda média e alta, vinculados aos eixos viários de maior mobilidade, sejam estes as rodovias ou as avenidas estruturais da cidade (Figura 1); e aqueles voltados às classes de menor renda, formados em sua quase totalidade por conjuntos habitacionais unifamiliares e multifamiliares, associados e articulados por avenidas radiais com forte presença de transporte público e, deste modo, marcando uma nítida divisão social dos espaços atuais de moradia. Vale reforçar, ainda com relação a Figura 1, a diferença entre os diversos indutores da expansão urbana. Enquanto a região sudoeste teve sua ocupação mais fortemente intensificada a partir da década de 1970 e esteve, desde o início, associada a duas vias principais de penetração no território: avenida das Amoreiras-Ruy Rodrigues e avenida John Boyd Dunlop, a região nordeste, por sua vez, começa consolidar sua ocupação de forma mais significativa somente desde a década de 1990, quando se completa a configuração atual do sistema rodoviário no entorno e a partir de Campinas.

Figura 1: Estruturação Viária do Município de Campinas.

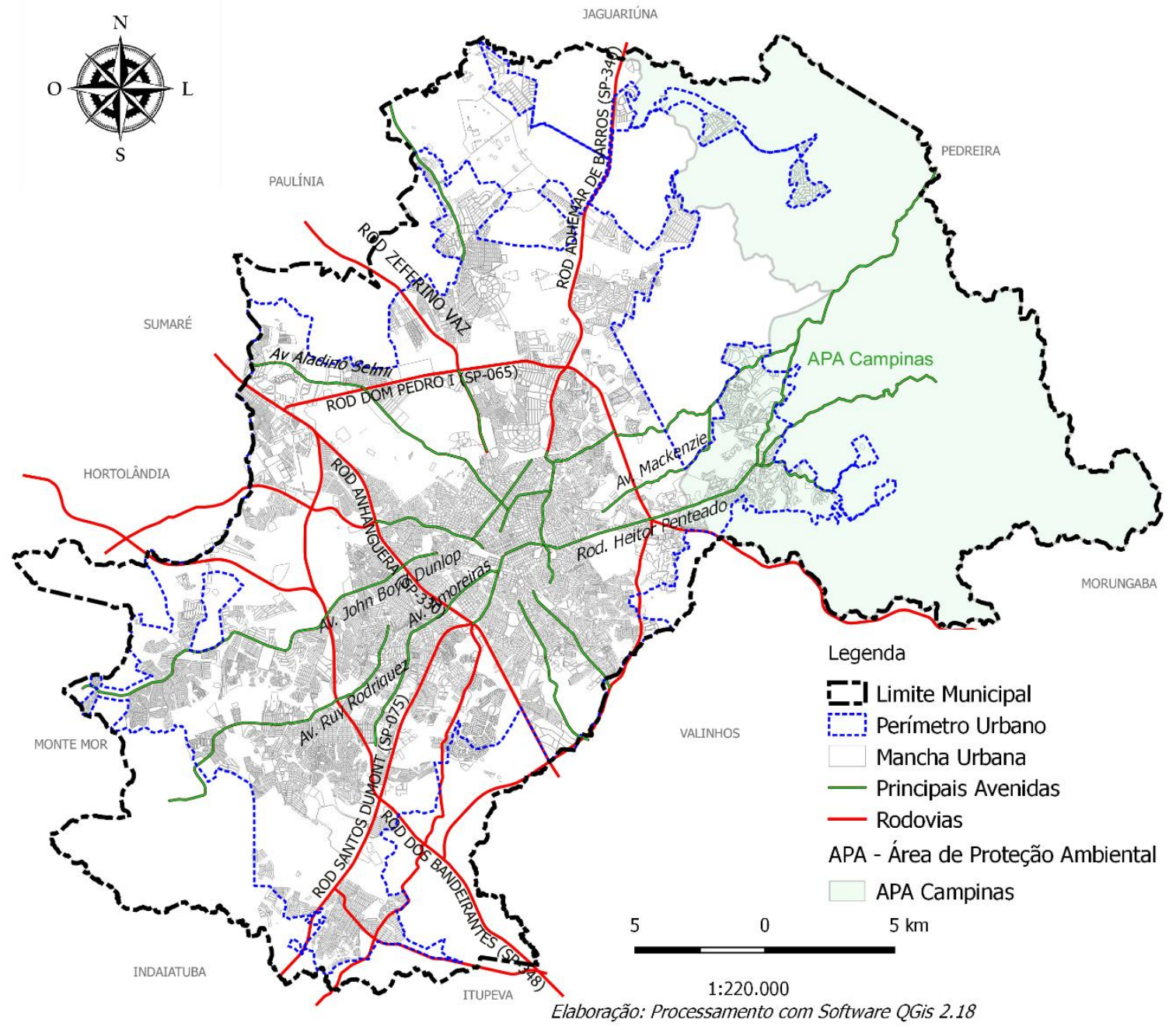

Fonte: BARBUTTI, 2019. 
Até esta década, 1970, a expansão urbana de Campinas ocorreu, ainda que plena de vazios urbanos, muito mais na região sudoeste e tocava bem mais ao assentamento da população de baixa renda. $O$ mundo suburbano de classe média em Campinas tem seus primeiros indícios somente a partir dos anos 1970, quando as grandes universidades se instalam fora da mancha urbana (Unicamp e PUC), quando também começa a ser implantado um novo e mais amplo sistema viário (rodovia D. Pedro I) que viria a se completar nos anos 1990, com a configuração da atual mobilidade rodoviária. Assim, a maior parte dos loteamentos implantados na parte nordeste da cidade, em sua maior parte loteamentos fechados, ocorre a partir dos anos 1990 e mais fortemente após a virada do século XX para o XXI.

Ainda com relação a reestruturação urbana se faz importante ressaltar as diferenças fundamentais na comparação entre contextos socioeconômicos distintos. Nos exemplos descritos por Soja (2008, pp. 342-343), com base no estudo de Los Angeles, a constituição dos subúrbios e posteriormente as cidades exteriores refere-se a um deslocamento das classes médias possuidoras de automóvel. Tratou-se de uma descentralização totalmente voluntária impulsionada pela suburbanização/descentralização do emprego e do consumo. Já no caso do Brasil, em especial Campinas, a descentralização inicial ocorre em função da ocupação periférica feita pela população de baixa renda na região sudoeste da cidade. Neste caso, tratou-se de uma descentralização totalmente involuntária. As formas de financiamento habitacional no Brasil fazem da população de baixa renda consumidores cativos de empreendimentos habitacionais financiados pelo poder público, e estes, de modo geral, foram instalados em terrenos fora da cidade, em direção aos fundos da região sudoeste e, inicialmente, com pouca ou nenhuma infraestrutura e serviços básicos.

Portanto, as diferentes formas de expansão urbana expressam, enquanto representação, uma divisão social do espaço urbano de características particulares e, apesar de suas semelhanças com processos gerais de reestruturação urbana, também uma espacialidade urbana contemporânea específica no que concerne a processos, agentes e a geografia da cidade de Campinas. A segregação residencial e a estrita distribuição espacial que se processa pelas diferentes classes de renda na cidade é um dos elementos mais fortes desse fenômeno. A renda está associada diretamente à acessibilidade e à qualidade da habitação. Sua localização em áreas com maior ou menor quantidade de infraestrutura e de equipamentos coletivos cristaliza um mosaico social com distintas formas e conteúdos sociais. $\mathrm{Na}$ verdade, tanto as infraestruturas quanto determinados equipamentos públicos são produzidos e localizados, em grande medida, respondendo a demandas de valorização imobiliária (HARVEY, 2014). Portanto, trata-se de uma topologia que desempenha um papel fundamental na estruturação desse mosaico social. 
Figura 2: Localização dos Loteamentos no município de Campinas-SP período 2000-2017.
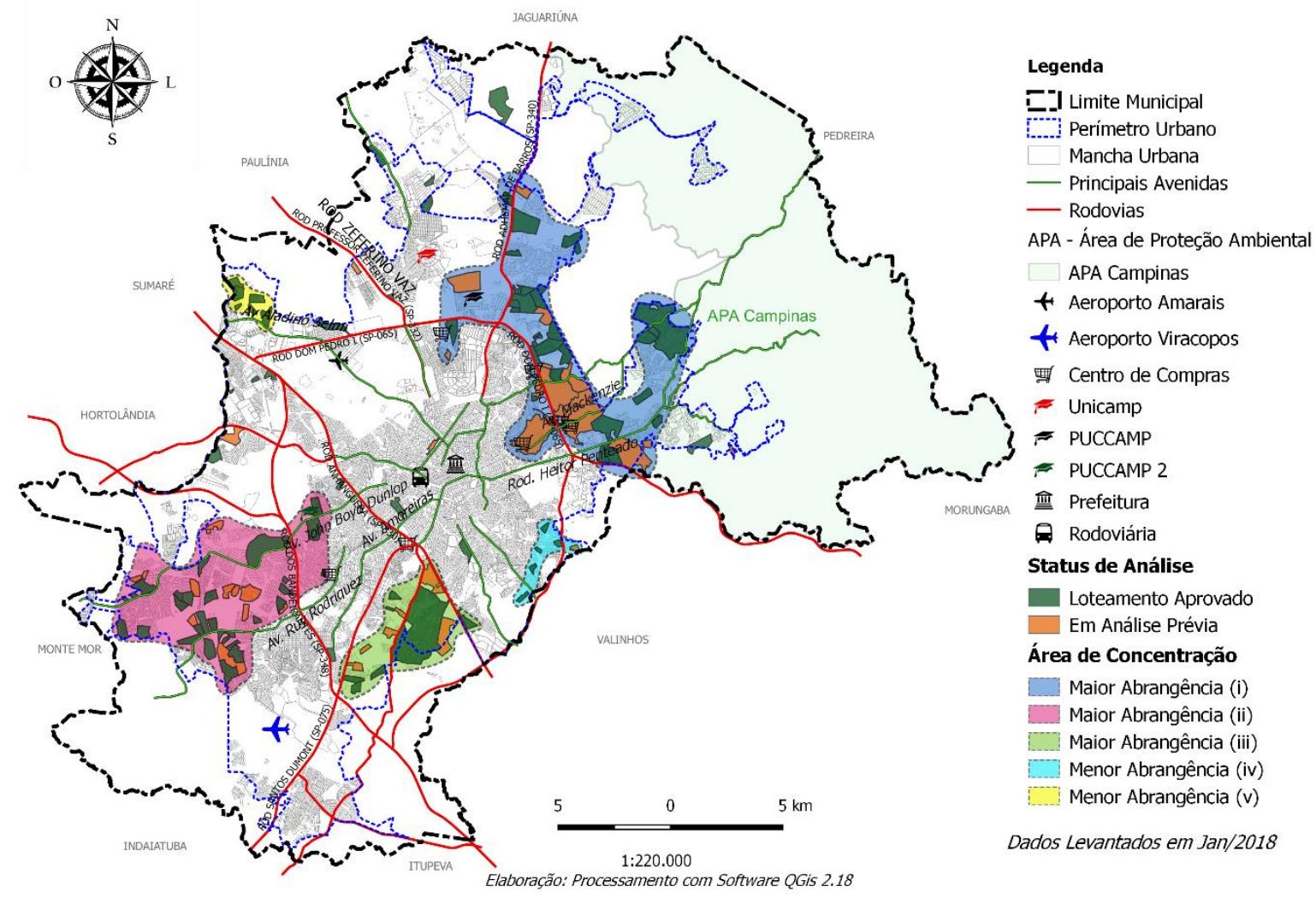

Dados Levantados em Jan/2018

Fonte: BARBUTTI, 2019.

A Figura 2 nos mostra a distribuição espacial dos loteamentos levantados no período de 2000 a 2017 na cidade, compreendendo um total de 128 áreas que deram entrada para aprovação, sendo que desse total 89 loteamentos se encontravam aprovados em 2017. A partir da Figura 2, é possível identificar três áreas de maior incidência de projetos aprovados de novos loteamentos e outras duas áreas secundárias com menor incidência.

As principais áreas que se destacam na Figura 2 tiveram sua ocupação induzida e articulada por diferentes estruturas viárias. Na região leste (i) a estruturação é feita a partir de três rodovias - Dom Pedro I (SP-65), Gov. Dr. Adhemar de Barros (SP-340) e Heitor Penteado (SP-81) - e também pelas principais avenidas radiais que cortam a rodovia D. Pedro I - as avenidas Mackenzie e Carlos Grimaldi. Nesta região, os loteamentos, incluídos na mancha azul (Figura 2), apresentam-se estreitamente vinculados a essas estruturas viárias e formam uma ocupação de peças isoladas que se estende desde a margem direita da rodovia Adhemar de Barros, ocupam os dois lados da rodovia D. Pedro I e adentram uma parte do distrito de Sousas. A região sudoeste (ii), marcada pela cor fúcsia na Figura 2, está estruturada pelas avenidas radiais John Boyd Dunlop e Ruy Rodriguez. São avenidas estruturadoras que estabelecem a ligação dos bairros populares com o centro tradicional da cidade $e$ que conformaram a ocupação desta parte da cidade desde os anos 1950. A região sul (iii), marcada em verde, está articulada pela rodovia Anhanguera (SP-330) próximo ao trevo com a Rod. Lix da Cunha (SP-073) e também, em parte, pela rodovia Santos Dumont. É uma região cuja ocupação apresenta tipologias e rendas bastante diversas. Por um lado, conjuntos habitacionais produzidos pelo programa MCMV, situados no interior da região e articulados por estruturas de mobilidade de menor importância, como a Rod. Lix da Cunha. Apesar do nome, esta rodovia, também conhecida como a estrada velha de Indaiatuba, é uma via asfaltada e, ao mesmo tempo, bastante precária do ponto de vista de articulação urbana. Por outro, a região é ocupada por loteamentos fechados articulados diretamente com a Rodovia Anhanguera. 
As duas áreas secundárias se apresentam de forma mais residual no território. Na região sudeste (iv), marcada em azul-claro, a ocupação ocorre em glebas menores, em uma área já consolidada do tecido urbano, próximo à divisa com o município de Valinhos. Nesta região, nos novos loteamentos, predominam empreendimentos do programa Minha Casa Minha Vida (MCMV) destinados principalmente a famílias enquadradas na faixa 2 do programa. A região noroeste $(\mathrm{v})$, marcada em amarelo, apresenta características semelhantes a anterior, porém faz divisa com o município de Sumaré e seu principal acesso se dá pela avenida Aladino Selmi, configurando sua expansão a partir de empreendimentos de interesse social destinados às faixas 1 e 1,5.

Portanto, tomando o conjunto dos loteamentos levantados, é possível destacar três áreas de maior incidência de loteamentos aprovados e também de maior magnitude (i, ii e iii), indicando a nítida divisão socioespacial que se estabelece entre os dois principais eixos de expansão: a nordeste os loteamentos fechados e a sul-sudoeste os conjuntos habitacionais. A única exceção no lado sulsudoeste, como veremos no decorrer deste artigo, são os condomínios fechados localizados próximos a rodovia Anhanguera e articulados diretamente a ela (incluídos em parte da área de abrangência iii, Figura 2), seguindo a mesma lógica das implantações localizadas na região nordeste.

No próximo tópico trataremos de analisar, mais especificamente, como ocorre a ocupação em cada uma dessas regiões (áreas de abrangência indicadas na figura 2).

\subsection{Expansão urbana em função da característica dos loteamentos: aberto ou fechado}

A Figura 3 traz uma nova possibilidade de abordar a expansão urbana, separando os loteamentos aprovados em abertos ou fechados. Em uma rápida caracterização sobre essas duas formas, podemos afirmar que os loteamentos fechados são marcados principalmente pela presença de muros que os separam fisicamente do restante da cidade, apresentam cercamentos em todo seu perímetro, não se articulando plenamente com a malha viária e formando grandes unidades isoladas. O padrão construtivo tem características próprias: são casas isoladas, com residências recuadas, espaços livres intralotes, jardins frontais e de fundos, piscinas e ruas bastante arborizadas, fatores permitidos pelo maior tamanho dos lotes. Os loteamentos fechados, no caso de Campinas, são aprovados como loteamentos abertos e depois ocorre a autorização de cercamento. Este procedimento transforma os espaços de uso público, aqueles doados no processo de parcelamento do solo, em espaços de uso coletivo dentro dos muros de fechamento, configurando assim, uma nova forma de morar, mudando os padrões dos espaços públicos e a própria relação dos moradores com estes.

Já os loteamentos abertos caracterizam-se por serem frutos de um processo de parcelamento em que os lotes ficam diretamente ligados às ruas, sendo estas de caráter e propriedade públicos, articulados à malha viária existente, ou seja, integrados à cidade preexistente.

A ocorrência dos loteamentos abertos, destacados em verde (Figura 3), está concentrada na porção sudoeste e noroeste do município, formando um total de sessenta áreas articuladas, em grande parte pelas avenidas radiais que ligam o centro a essa periferia. Os loteamentos fechados, destacados em vermelho (Figura 3), têm um universo de 29 áreas e se concentram próximos às principais rodovias existentes nas partes norte e leste da cidade. Especificamente nesta região os loteamentos fechados aparecem pontualmente desde a década de 1980, entretanto, é a partir do final da década de 1990 que sua expressão se torna mais fortemente visível na paisagem da expansão urbana da cidade. A única exceção de localização dessa forma de ocupação, como já foi dito, é o conjunto de loteamentos fechados da região (iii), articulados diretamente à rodovia Anhanguera. 
Figura 3: Localização dos loteamentos do tipo aberto e fechado no município de Campinas, SP período 20002017.

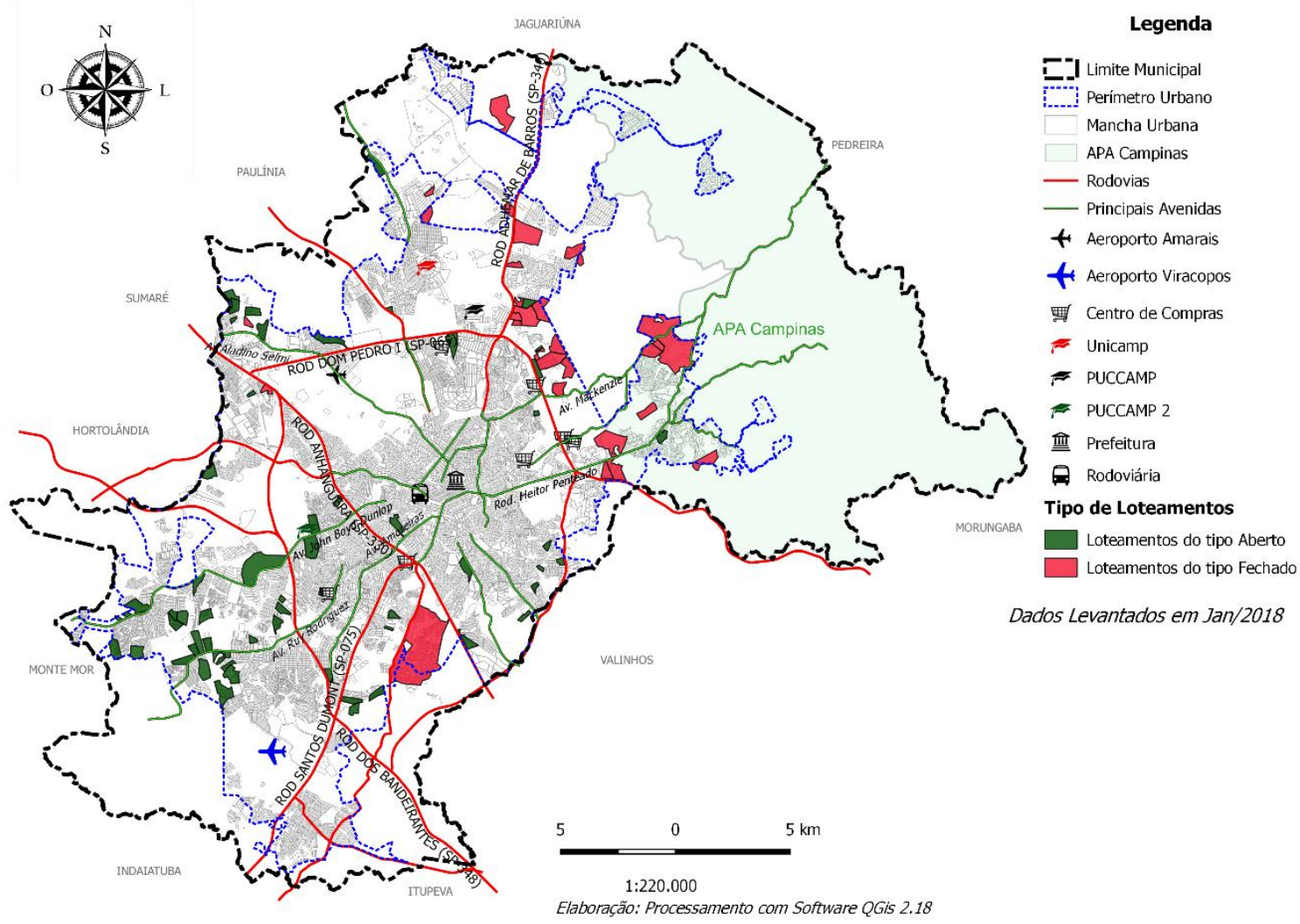

Fonte: BARBUTTI, 2019

$\mathrm{Na}$ expansão urbana de Campinas a figura dos loteamentos fechados aparece como peça importante na ocupação de parte significativa do território. É uma região de ocupação recente, onde se concentram os segmentos sociais de maior poder aquisitivo. Também caracteriza a ocupação desta área o fato de, historicamente, ocorrer uma associação entre acessibilidade e valor da terra, selecionando as atividades que ali se instalam. A configuração da expansão urbana desta parte da cidade é também expressa pela maior disponibilidade de empregos de mão de obra especializada (indústria e serviços ligados a setores de tecnologia) e também pela mobilidade decorrente da difusão do uso do automóvel.

Essa forma de parcelamento - loteamento fechado -, juridicamente, permanece ainda bastante polêmica em função dos problemas legais existentes em sua aprovação. Em Campinas, foi normatizada pela Lei Municipal oㅜ 8.736/1996, a qual dispõe sobre a permissão a título precário de uso das áreas públicas de lazer e das vias de circulação, permitindo um muro de fechamento dos logradouros públicos como vias de circulação, áreas de lazer, áreas verdes, que terão seu acesso controlado. Trata-se da privatização de áreas que são da coletividade, sem nenhum tipo de compensação pelo dano causado pelo fechamento. Nesta modalidade, não há a produção de edificações de imediato, apenas a aprovação e implantação de lotes.

Apesar do fechamento ocorrer posteriormente à aprovação e mediante anuência da prefeitura, cabe ressaltar que o projeto urbanístico já é pensado e desenhado em função de seu fechamento. Destacase, nesse sentido, o sistema de lazer que cria um cinturão de fechamento e também as vias terminadas em cul-de-sac, representado pelo modelo "espinha de peixe", conforme observado na Figura 4. Esta configuração de desenho é um dos principais artifícios usados pelos agentes imobiliários para a internalização dos lotes onde, ao final, torna-se possível construir o muro de isolamento. Ainda no exemplo da Figura 4, importa ressaltar que as áreas destinadas aos usos institucionais ficam 
externas aos muros do loteamento, mas confinadas entre os muros dos demais empreendimentos organizados como ilhas, unidades isoladas. Além disso, como esses equipamentos não são demandados pela população, essas áreas destinadas aos usos institucionais permanecem indefinidamente como vazios e sem nenhuma possibilidade de vir a ter uma função pública. Esses espaços, na acepção de Harvey, jamais virão a atender interesses comuns como seria de seu caráter e natureza originais (HARVEY, 2014).

Figura 4: Modelo de loteamento fechado, com vias em cul-de-sac e sistema de lazer de fechamento.

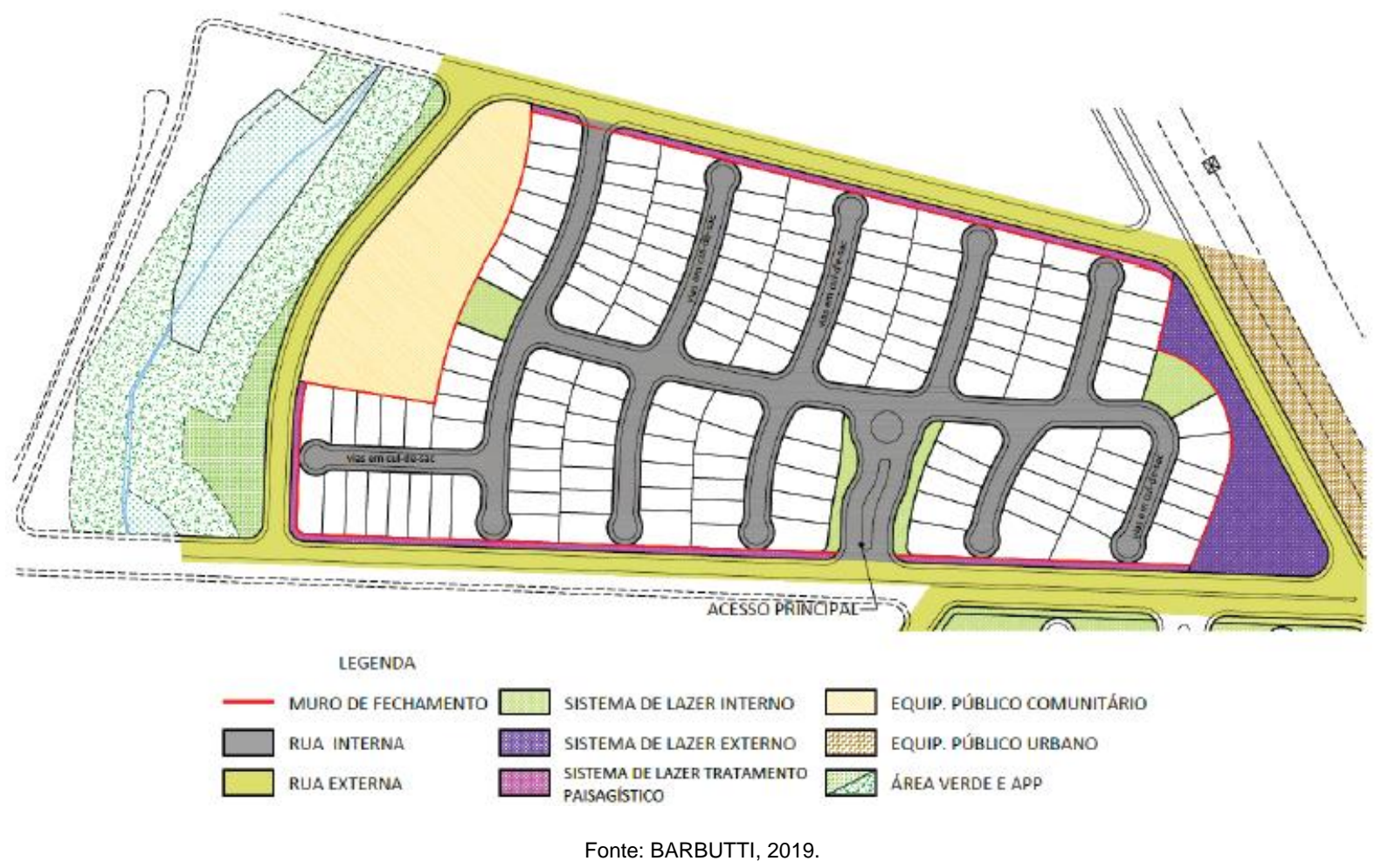

Caldeira (1997) define este tipo de espaço como um "enclave fortificado" que, constituindo-se de espaços "fechados e monitorados para residência, consumo, lazer ou trabalho [...], geram cidades fragmentadas em que é difícil manter os princípios básicos da livre circulação e da publicidade de seus espaços públicos". Estas formas de expansão urbana e de criação de cidades reproduzem um modelo de degradação ambiental e segregação socioeconômica, em que a população é distribuída no território de acordo com seu pertencimento à determinada classe de renda, caracterizando espaços socialmente homogêneos.

Os loteamentos fechados nada mais são do que a espacialização da autossegregação ${ }^{1}$ que se manifesta por meio de áreas nas quais se concentram grupos sociais de relativa homogeneidade, viabilizando a existência e reprodução dos mesmos. Soja (2008, pp. 340-341) afirma que essa forma de urbanização está se convertendo em um modo de vida com especificidades espaciais. No caso de Campinas, já é possível perceber a existência de um modo de vida que em grande parte se autonomiza em relação à cidade central, rompendo com o mundo monocêntrico da metrópole industrial do século $X X$ e instalando a predominância dos deslocamentos periferia-periferia em detrimento dos deslocamentos anteriores que se faziam predominantemente entre a periferia e 0 centro. Estas áreas segregadas, de acordo com Corrêa (2018, pp. 44), estão dispostas "com uma

\footnotetext{
${ }^{1}$ Autossegregação é quando as pessoas de classes sociais de alto poder aquisitivo constroem novas formas de organização social e agrupam-se em loteamentos fechados, normalmente distantes dos centros urbanos. Não se trata de uma "escolha", pois eles tentam escapar dos problemas das cidades. "Os que se autossegregam, na condição de moradores, são, em grande parte, os mesmos que, na condição de elite dirigente, são, ao menos, corresponsáveis pela deterioração das condições de vida na cidade, inclusive no que se refere à segurança pública" (SOUZA, 2013, p. 71).
} 
lógica espacial variável, que as inscrevem no espaço urbano, gerando padrões espaciais de segregação residencial ou modelos" que neste caso se manifestam através da forma de loteamentos fechados.

\subsection{Expansão urbana em função do tipo de lote produzido}

Os lotes produzidos podem ser unifamiliares ou multifamiliares. Os tipos unifamiliares são "destinados exclusivamente ao uso residencial, com apenas uma unidade edificada de habitação por lote". Os tipos multifamiliares são "destinados exclusivamente ao uso residencial, isolados ou agrupados horizontal e/ou verticalmente, com mais de uma unidade edificada de habitação por lote e com espaços e instalações de uso comum ${ }^{3}$ ". Esses agrupamentos edificados e providos de algum tipo de cercamento são conhecidos como condomínios.

Figura 5: Localização dos loteamentos por tipos de lotes produzidos
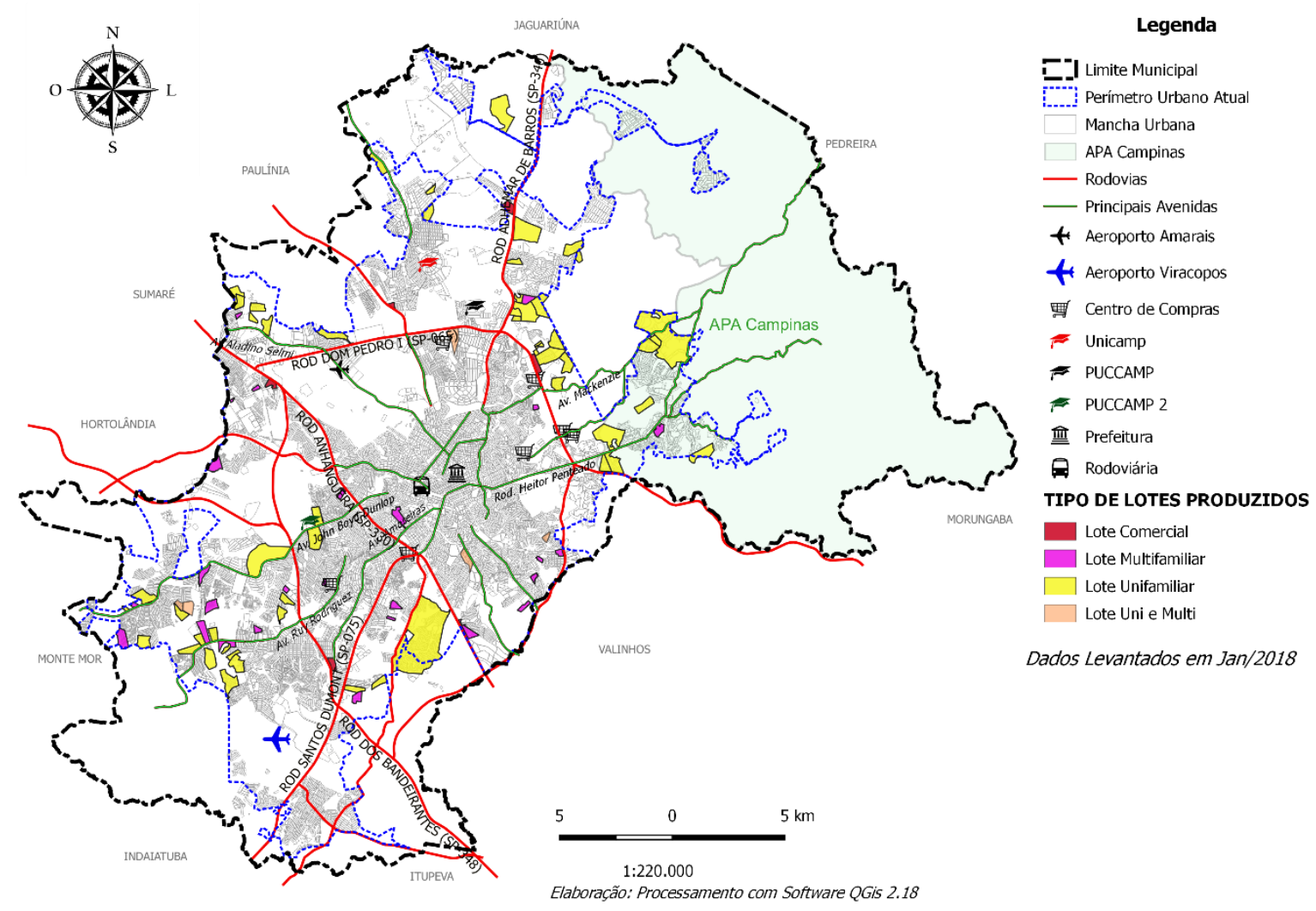

Fonte: BARBUTTI, 2019.

O tipo unifamiliar congrega 53 loteamentos do universo de 89 loteamentos levantados e estão destacados em amarelo na Figura 5, que estão concentrados nas regiões de expansão urbana nortenordeste e são também encontrados na região sudoeste da cidade. Comparando as Figuras 3 e 5 podemos afirmar que os loteamentos unifamiliares das regiões norte e nordeste são empreendimentos fechados enquanto os da região sudoeste são abertos e correspondem, em geral, a conjuntos de casas produzidos por programas oficiais de habitação de interesse social. A Figura 6 apresenta um agrupamento de lotes unifamiliares, um loteamento aberto de interesse social típico da urbanização da região sudoeste. Aberto ou fechado, a tipologia não muda, a diferença reside nas dimensões e na forma como o conjunto de lotes unifamiliares se relaciona com a cidade.

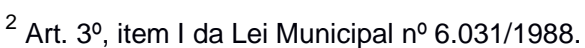

${ }^{3}$ Art. $3^{\circ}$, item II da Lei Municipal $n^{\circ}=6.031 / 1988$.
} 
Figura 6: Tipo de implantação de lotes unifamiliar

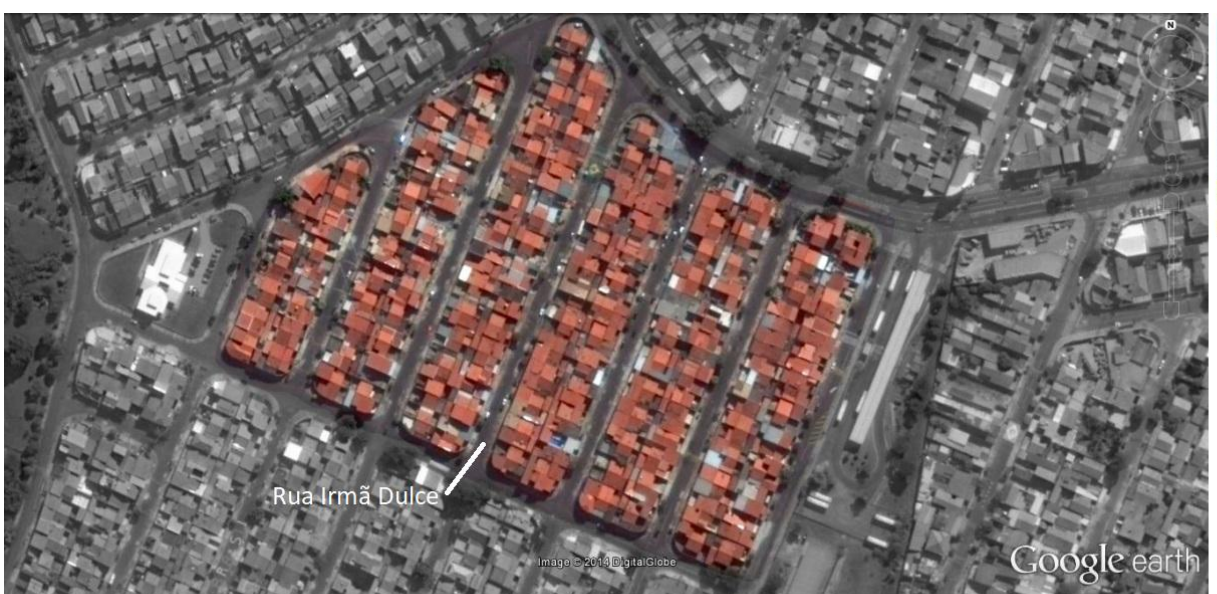

BAIRRO VILA UNIÃO

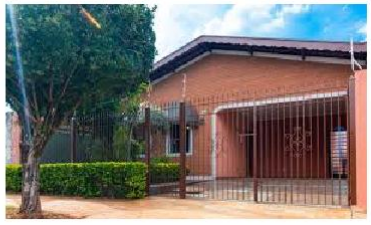

HABITAÇÃO UNIFAMILIAR

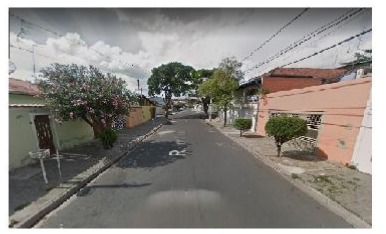

RUA IRMÃ DULCE

Fonte: Google Earth, 2017

O tipo multifamiliar soma 26 loteamentos, e a Figura 7 mostra uma possibilidade de ocupação com lotes multifamiliares. Neste caso, trata-se de um empreendimento habitacional de interesse social (EHIS), com lotes grandes (até $10 \mathrm{mil} \mathrm{m}$ ), ocupados por vários prédios de até cinco pavimentos. Os empreendimentos desse tipo são, em geral, mais densos, organizados na forma de condomínios, com blocos consecutivos e estacionamento ao centro. A implantação desses grandes conjuntos, com muitas unidades habitacionais, produzidos e ocupados de uma só vez, pressionam fortemente o poder público quanto à necessidade de oferta imediata de serviços públicos de saúde, educação, transporte público e também das infraestruturas básicas. Esta forma de ocupação torna-se ainda mais grave por tratar-se de um território onde a precariedade é a regra. Uma questão importante apontada por Shimbo é que:

não se trata apenas do binômio Estado-mercado, mas, sobretudo, de uma articulação específica entre ambos, que existe quando se opera a partir da lógica privada de produção da habitação e quando se encara a moradia como "mercadoria". (SHIMBO, 2012, p. 26)

Esta tipologia (multifamiliar e condominial) ocorre de forma predominante nos empreendimentos destinados a população de baixa renda e, como indicado na Figura 5, estão predominantemente localizados na região sudoeste. Portanto, a forma da implantação e organização desses conjuntos, numa associação entre empresas privadas e diferentes atores públicos, tem provocado uma deterioração da cidade e da vida pública nesta porção do território campineiro. 
Figura 7: Tipo de implantação de lotes multifamiliar

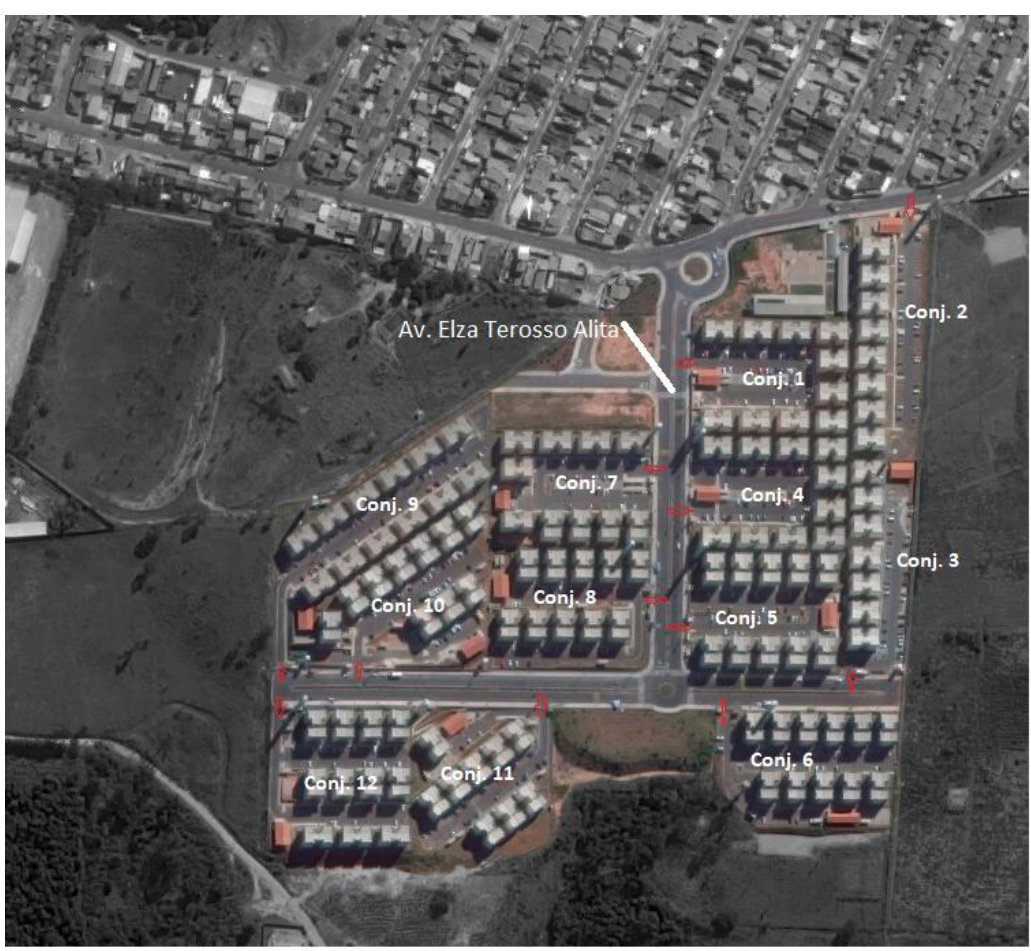

VILA ABAETE $\longrightarrow$ Acesso da via pública

Fonte: Google Earth, 2018

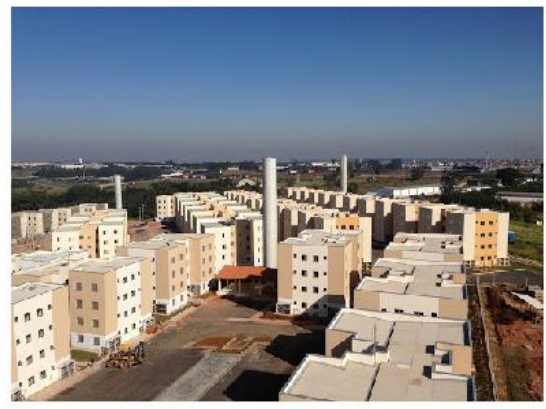

CONJ. HABITACIONAL

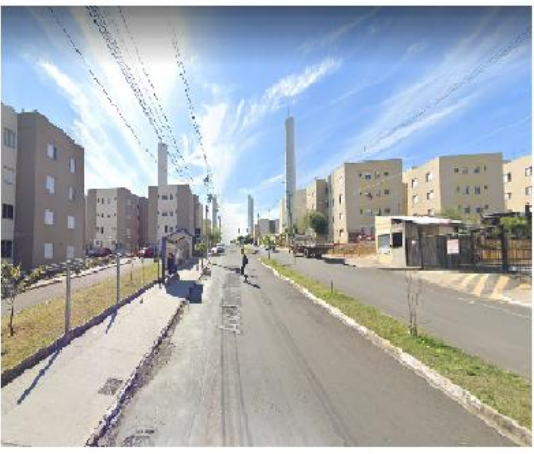

AV. ELZA TEROSSO ALITA

\subsection{Expansão urbana por tipo de uso dos loteamentos}

De acordo com a solicitação de aprovação, a prefeitura de Campinas classifica os loteamentos por tipo de uso em: residencial, empreendimento habitacional de interesse social (EHIS) ${ }^{4}$ e comercial (Figura 8). Do conjunto de loteamentos aprovados no período considerado, ou seja, de 89 loteamentos, 49 são residenciais, 35 correspondem a EHIS e apenas cinco são de uso comercial.

\footnotetext{
${ }^{4}$ Os EHIS são aprovados por uma legislação específica, a Lei Municipal no 10.410/2000, que estabelece parâmetros distintos para esta tipologia, constituindo-se de lote unifamiliar mínimo com área de 126 metros quadrados e frente de sete metros e para lotes multifamiliares área de no máximo 10 mil metros quadrados. O tipo residencial segue as regras da Lei de Uso e Ocupação do Solo (LUOS), onde o tamanho mínimo do lote unifamiliar é definido conforme cada zoneamento. Por exemplo, para a Zona 3 , que é maior parte da cidade, o lote mínimo deverá ter área de 250 metros quadrados e frente de dez metros. Essa diferenciação traz um viés econômico e de segregação social, isto é, permite que os EHIS utilizem parâmetros urbanísticos de forma a gerar padrões de urbanização inferiores ao restante da cidade.
} 
Figura 8: Tipo de uso dos loteamentos

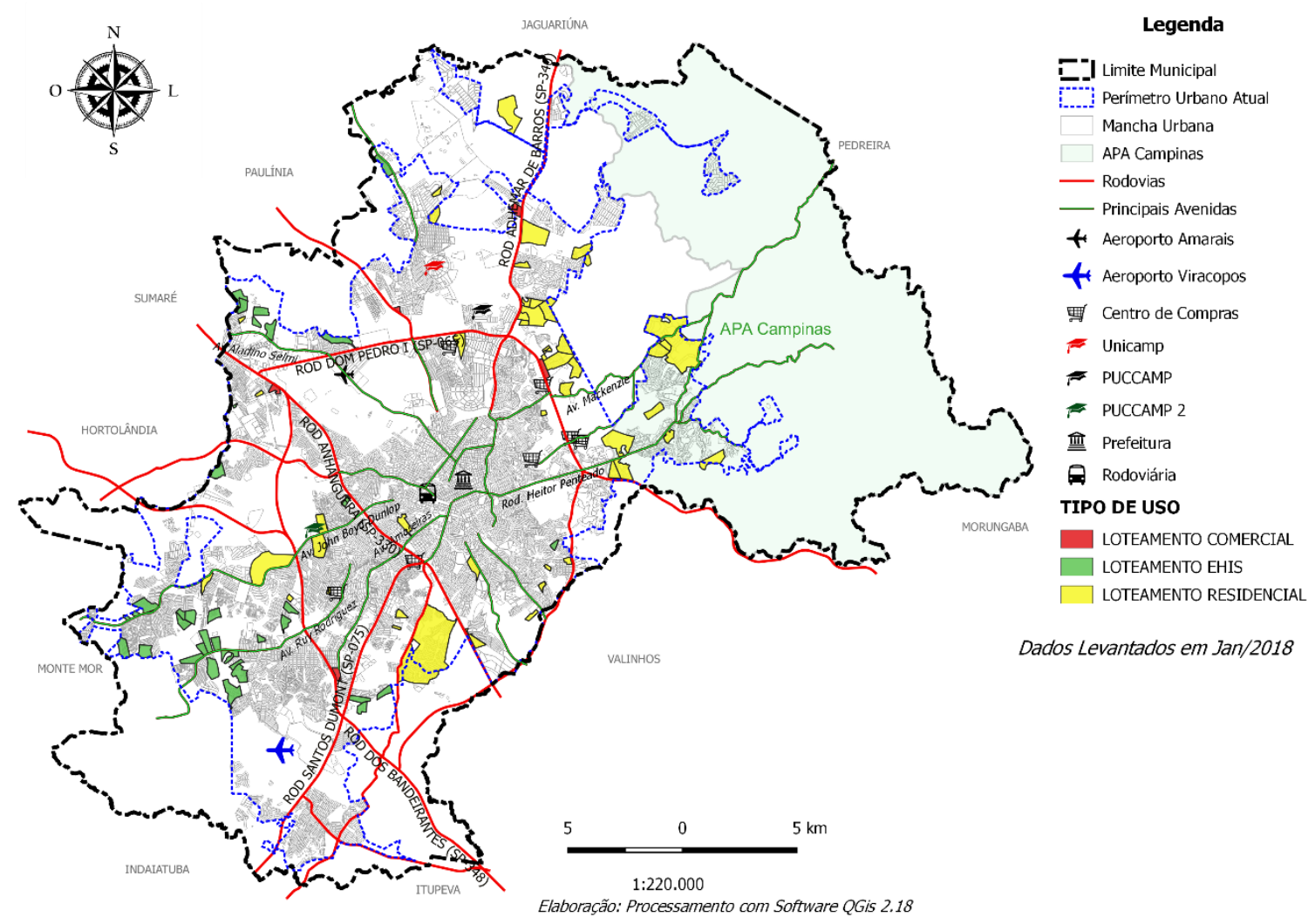

Fonte: BARBUTTI, 2019.

Os loteamentos do tipo comercial, indicados em vermelho na Figura 8, estão condicionados a uma zona específica definida pelo zoneamento da cidade. São loteamentos de uso exclusivo de comércio, serviços e negócios, apresentando dimensões de lotes muito variadas, entre 250 a 10 mil metros quadrados, podendo, em casos especiais, superar os 20 mil metros quadrados. Pela gama de atividades incluídas nesta categoria e por causa das formas contemporâneas de organização das atividades - shoppings, lojas de departamentos, transportadoras, logística e conjunto de escritórios -, os empreendimentos demandam lotes com áreas bastante amplas para sua implantação. Além disso, estes empreendimentos obedecem a uma lógica de localização própria, ocupando espaços em geral articulados a vias de circulação rápida. Situam-se preferencialmente na confluência das rodovias com as avenidas estruturais da cidade.

O tipo residencial inclui loteamentos projetados para uso predominantemente habitacional residencial, podendo haver alguns poucos lotes destinados a atividades de comércio e serviços de caráter local. Somam 48 os loteamentos residenciais, destacados em amarelo na Figura 8. Podem ser abertos ou fechados, compostos de lotes unifamiliares ou multifamiliares e diferem dos loteamentos tipo EHIS em função de legislação específica. Na porção sudoeste há um destaque para um grande loteamento residencial aberto localizado ao longo da avenida John Boyd Dunlop. Trata-se de um conjunto que, apesar de estar em uma região onde predominam EHIS, não se utilizou dos parâmetros específicos para este tipo de empreendimento.

O loteamento do tipo EHIS, apesar de integrar o uso residencial, está submetido a parâmetros específicos baseados na Lei Municipal oㅜ 10.410/2000. Dos 89 loteamentos identificados, esta categoria contribui com 36 entre lotes unifamiliares e multifamiliares (Figura 9).

O lote unifamiliar, como decorrência de legislação específica de EHIS, possui área mínima de 126 metros quadrados e testada mínima de sete metros. Para os lotes não destinados ao interesse social, 
metragens mínimas são: 250 metros quadrados e dez metros de testada mínima. Os lotes residenciais multifamiliares poderão ser projetados em área cujas dimensões, em função da legislação, variam da área mínima de quinhentos à máxima de 10 mil metros quadrados para abrigar EHIS na forma de conjuntos habitacionais (em lote multifamiliar).

Comparando as Figuras 3 e 8, é possível destacar que o tipo residencial unifamiliar não pertencente a categoria EHIS é predominante na expansão urbana do norte-nordeste da cidade e integra de forma exclusiva a categoria loteamento fechado. Já os que se situam nas regiões sul e sudeste estão na categoria abertos e são, em sua maioria, empreendimentos de interesse social situados no fundo do território, em áreas consideradas de expansão urbana. Estes empreendimentos, como vimos, apesar de serem totalmente dependentes dos serviços e equipamentos públicos, estão ocorrendo em áreas consideradas precárias e/ou desprovidas de serviços e equipamentos públicos.

Figura 9: Loteamento com lotes multifamiliar

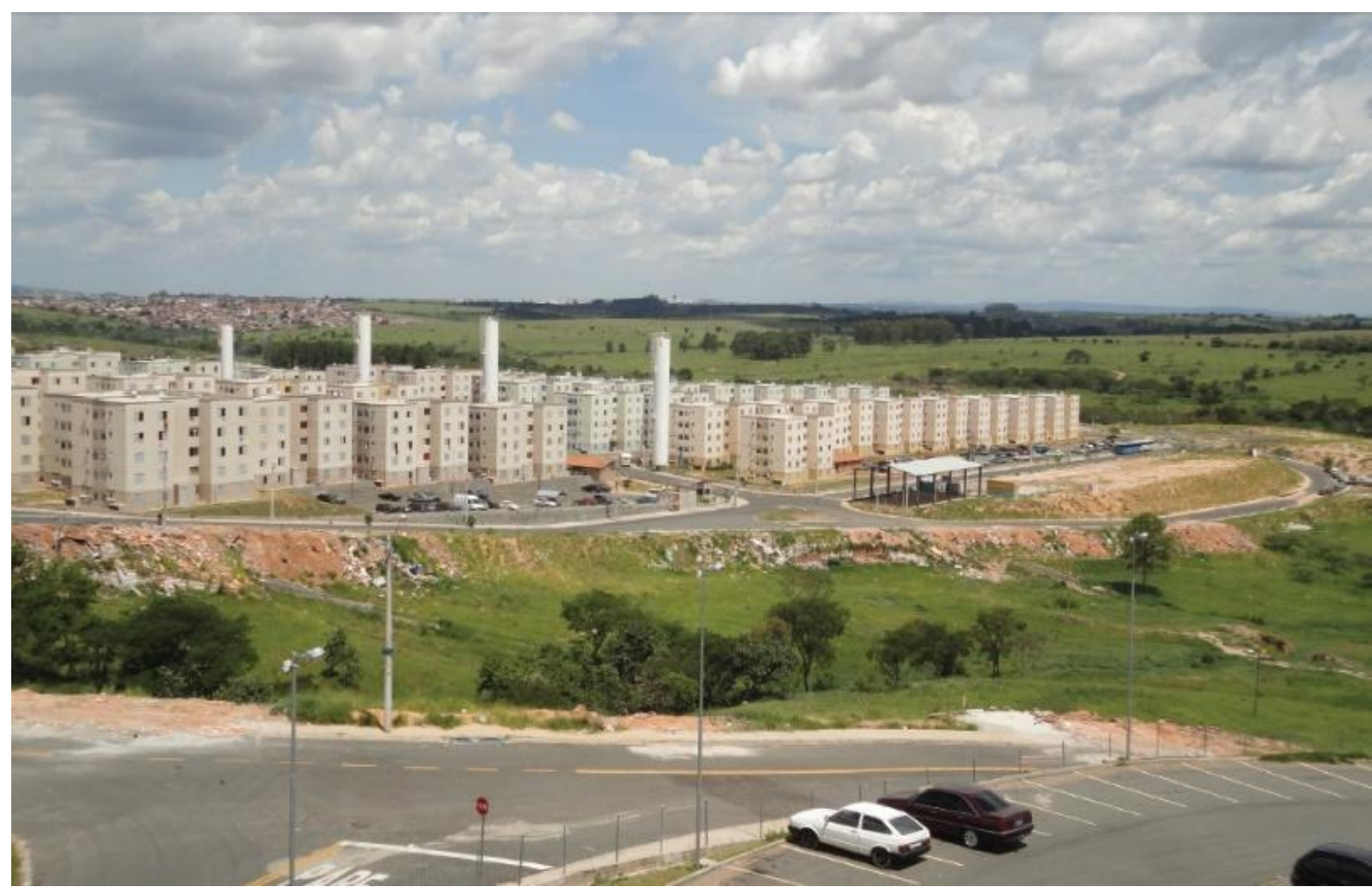

Fonte: Google Earth, 2017

Os conjuntos habitacionais (EHIS) efetivamente implantados em Campinas têm um padrão de uso do solo de caráter extremamente monofuncional, com predominância do uso residencial e uma presença incipiente de atividades comerciais e serviços. Nos casos de conjunto de prédios, há a presença de muros que contornam o empreendimento e a guarita na entrada. Esse padrão em muito se parece com à ideia dos "enclaves fortificados", desenvolvido por Caldeira (1997), todavia, a autora tinha se baseado nos empreendimentos residenciais de alto padrão. De acordo com Shimbo (2012), a forma destes "enclaves" associado a "classe C', representa uma cópia reduzida das tipologias encontradas nos empreendimentos da "classe A", isto é, ocorreu uma diminuição das dimensões das unidades, entretanto seguem de perto as mesmas lógicas dos "produtos" de alto padrão oferecidos pelo mercado. Com isso, os espaços de lazer foram reduzidos àquilo que sobra entre as edificações, uma vez que o princípio que rege a implantação das edificações EHIS é de ordem econômica, o que significa uma taxa de ocupação máxima, em detrimento dos espaços livres, de lazer e de circulação.

\footnotetext{
${ }^{5}$ Trata-se de espaços privatizados, fechados e monitorados para residência, consumo, lazer e trabalho.
} 


\section{Resultado e discussão}

Através da análise das Figuras 3, 5 e 8, representando os tipos de loteamentos, foi possível identificar duas morfologias urbanas predominantes que vêm ocorrendo separadamente em partes distintas da cidade, marcadas por uma divisão clara no território municipal (Figura 10). De um lado, identificados como Área de Concentração de Loteamentos EHIS (ACL-E) e situados de forma exclusiva na região sudoeste do município, os loteamentos estão articulados a partir de duas importantes avenidas estruturais (avenida John Boyd Dunlop e eixo avenidas Amoreiras-Ruy Rodriguez), sendo as principais conexões da região ao centro da cidade. Estes empreendimentos estão inseridos em um contexto urbano historicamente ocupado por conjuntos habitacionais. Os empreendimentos que compõem a ocupação atual, os novos conjuntos habitacionais, expandem essa área historicamente carente e infradotada dos principais serviços públicos ofertados pelo Estado.

De outro lado e bastante separada geograficamente temos a Área de Concentração de Loteamentos Fechados (ACL-F), situada à margem da rodovia D. Pedro I e englobando o trecho desde a rodovia Heitor Penteado que liga o centro da cidade ao distrito de Sousas, o entroncamento com a rodovia Adhemar de Barros, interceptado pelas avenidas radiais Mackenzie e Carlos Grimaldi. Observa-se nas manchas marcadas em vermelho (Figura 10) uma área exclusiva de loteamentos fechados destinados a população de rendas média e alta.

Figura 10: Localização das áreas de expansão urbana

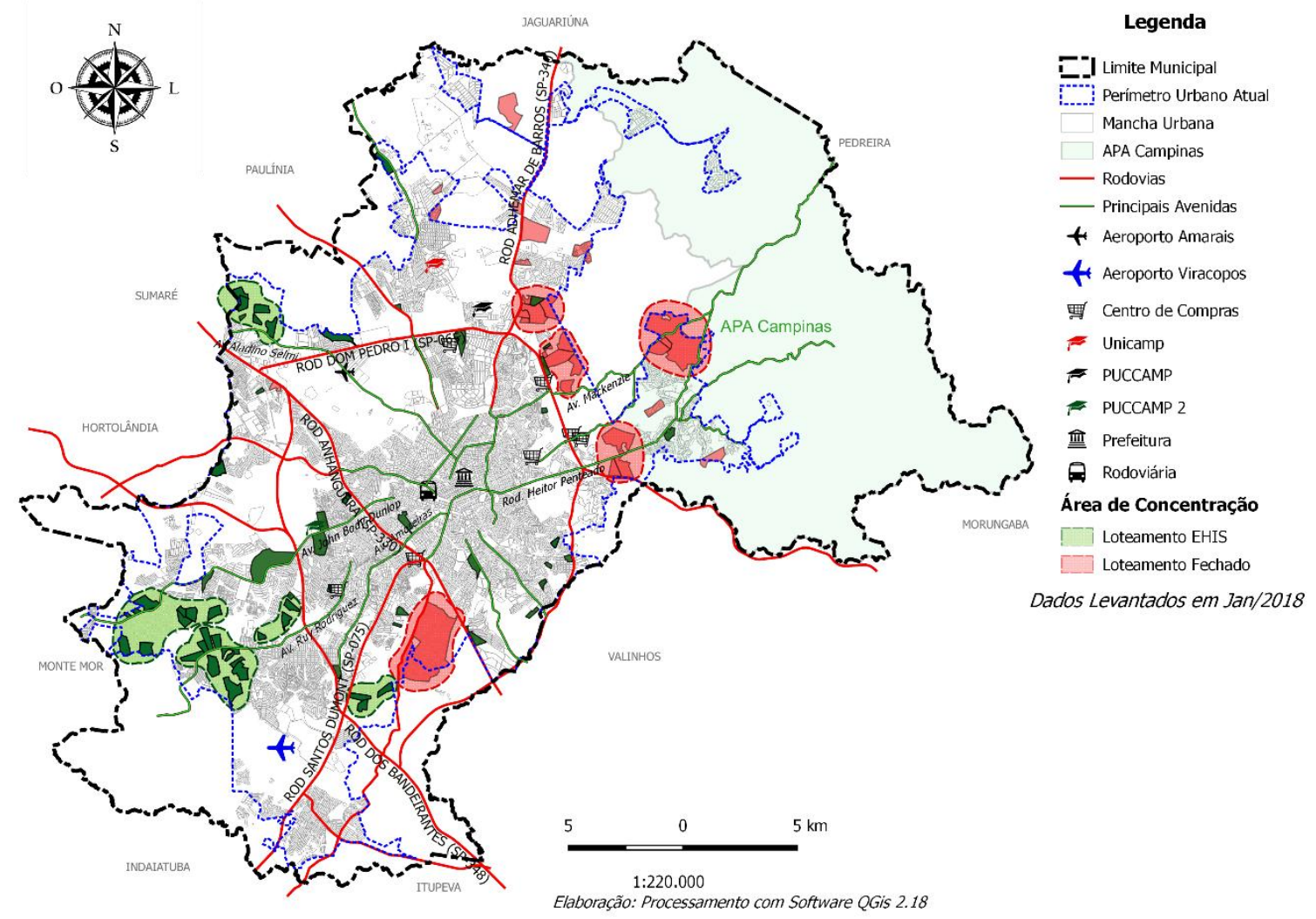

Fonte: BARBUTTI 2019

\subsection{Expansão urbana: Área de Concentração de loteamentos EHIS}

De acordo com dados levantados, tomando como referência a Tabela 1, é perceptível a diferença entre os valores do metro quadrado dos lotes unifamiliares para o conjunto de loteamentos EHIS em relação aos loteamentos fechados, onde sua localização está demarcada em verde (Figura 10). Observa-se uma concentração de loteamentos EHIS que se situam no extremo sudoeste da cidade, na divisa com 
o município de Monte Mor, em uma região de vazios urbanos e de urbanização precária e inacabada desde as décadas de 1950 e 1960.

Tabela 1: Valor do $\mathrm{m}^{2}$ de loteamentos com lotes unifamiliares

\begin{tabular}{|c|c|c|c|c|c|c|}
\hline \multicolumn{2}{|c|}{ Tipologia } & \multirow{2}{*}{$\begin{array}{c}\begin{array}{c}\text { Valor }^{2} \\
\text { UFIC }\end{array} \\
114\end{array}$} & \multicolumn{2}{|c|}{$\begin{array}{l}\text { Valor em R\$ } \\
\text { do } \mathrm{m}^{2} \mathrm{em} \\
2018\end{array}$} & \multirow{2}{*}{$\begin{array}{c}\text { No de } \\
\text { lotes }\end{array}$} & \multirow{2}{*}{$\begin{array}{c}\begin{array}{c}\text { Tamanho médio dos } \\
\text { lotes }\left(\mathbf{m}^{\mathbf{2}}\right)\end{array} \\
150,00\end{array}$} \\
\hline Aberto & \multirow{5}{*}{ EHIS } & & $\mathbf{R} \$$ & 386,53 & & \\
\hline Fechado & & 116 & $\mathbf{R} \$$ & 393,31 & 285 & 142,50 \\
\hline Aberto & & 143 & $\mathbf{R} \$$ & 484,86 & 358 & $140,00 / 160,00 / 200,00$ \\
\hline Aberto & & 168 & $\mathbf{R} \$$ & 569,62 & 1241 & 126,00 \\
\hline Aberto & & 168 & $\mathbf{R} \$$ & 569,62 & 982 & 126,00 \\
\hline Fechado & \multirow{6}{*}{ Residencial } & 185 & $\mathbf{R} \mathbf{\$}$ & 627,26 & 266 & 480,00 \\
\hline Fechado & & 185 & $\mathbf{R} \$$ & 627,26 & 234 & 450,00 \\
\hline Fechado & & 192 & $\mathbf{R} \$$ & 651,00 & 51 & $1.000,00$ \\
\hline Fechado & & 228 & $\mathbf{R} \$$ & 773,06 & 721 & 360,00 a 470,00 \\
\hline Fechado & & 256 & $\mathbf{R} \mathbf{S}$ & 867,99 & 65 & $1.000,00$ \\
\hline Fechado & & 395 & $\mathbf{R} \$$ & $1.339,29$ & 267 & 460,94 a $1.000,00$ \\
\hline
\end{tabular}

Fonte: Coordenadoria de Parcelamento do Solo, 2017.

Apesar de não haver restrição locacional no território municipal urbano, os EHIS estão concentrados em áreas onde o preço da terra atua como fator locacional determinante. O fato de nas últimas décadas esses empreendimentos terem sido produzidos em associação com a iniciativa privada é altamente relevante na escolha das áreas. Portanto, a escolha das áreas para moradia popular tem reforçado um padrão histórico de ocupação e, ao mesmo tempo, faz aumentar as desigualdades e a segregação socioespacial já existente.

\subsection{Expansão urbana: Área de Concentração de Loteamentos Fechados}

Os empreendimentos aprovados nesta parte da cidade (Figura 10, áreas destacadas em vermelho) têm características bastante distintas dos empreendimentos EHIS da região sudoeste. São em geral lotes unifamiliares, com dimensões mínimas de 420 metros quadrados, sendo que alguns podem superar mil metros quadrados. Nestes casos, a relação de espaço público e privado tem outra lógica de estruturação e consequentemente formas de apropriação pela população. De acordo com Freitas (2008), os espaços que estão no intramuros têm como principal objetivo a formação de comunidades mais integradas. Os consumidores deste tipo de "produto" buscam nos espaços livres, ruas e sistema de lazer a tranquilidade oferecida pelo cercamento. Além do mais, a imposição do controle permite maior segurança dos espaços internalizados, bem como a homogeneização do perfil dos seus moradores.

Sua ocupação, ao longo dos últimos quarenta anos, está associada aos eixos de mobilidade e se apresenta de forma muito distinta do restante da cidade. A implantação desses empreendimentos responde a uma lógica própria. Além de sua associação com os eixos de mobilidade, apresentam-se no território como unidades isoladas, cercadas. Por outro lado, apresentam-se também articuladas por atividades ligadas ao consumo, aos serviços e também a produção (indústrias). Em suma, às atividades geradoras de emprego e facilitadoras de um modo de vida em torno de atividades periféricas. Esta situação tem atuado como um elemento polarizador da ocupação periférica a partir loteamentos fechados. Vale destacar como exceção a este universo o conjunto de loteamentos fechados denominado Swiss Park, localizado na parte sul da cidade e vinculado à mobilidade proporcionada pela rodovia Anhanguera. 


\section{Conclusões}

Os avanços mais significativos da pesquisa se relacionam à comprovação, por meio do levantamento dos tipos de loteamentos que se caracterizam por duas formas predominantes de expansão no município de Campinas, as quais se diferem e se espacializam em situações bem específicas: os loteamentos destinados a EHIS na região sudoeste e os loteamentos fechados destinados às classes de renda média e média alta na parte nordeste da cidade.

Os loteamentos EHIS estão associados, principalmente às vias de penetração no território, as avenidas Amoreiras, Ruy Rodriguez e a avenida John Boyd Dunlop. Sua localização está, em grande medida, relacionada e dependente dos serviços públicos de transporte, saúde, educação, assim como sua urbanidade está vinculada aos espaços públicos de convívio e lazer.

Por outro lado, os loteamentos fechados estão associados às rodovias e vias urbanas expressas conectadas a essas rodovias. Esses loteamentos se estabelecem com grande independência dos serviços e dos transportes públicos; mais do que isso, estabelecem certa autonomia em relação à cidade em sua expressão tradicional, com seu centro. Localizam-se, em geral, com outra referência de acessibilidade e mobilidade, muito vinculada ao transporte individual e a outra escala urbana. São implantados na cidade como unidades autônomas e em geral vinculados aos novos centros de consumo e lazer, estes também associados às estruturas rodoviárias e vias expressas e referenciados em uma escala territorial bem mais ampla do que o município.

$\mathrm{Na}$ região sudoeste, os empreendimentos habitacionais de interesse social (ACL-E) tanto em lotes para casas como em condomínios de prédios, estão localizados nas franjas da cidade, ocupando áreas que ainda sofrem sérios problemas de carência e/ou precariedade de infraestrutura e serviços públicos.

É uma região periférica ocupada, com pouca diversidade funcional, em um tecido urbano fragmentado ${ }^{6}$ social e espacialmente. A urbanização recente a partir de loteamentos EHIS apresentada nesta pesquisa mostra a reiteração de uma forma de expansão urbana que é, por si só, reprodutora das carências e segregações que há décadas afetam a região. Este território, portanto, é produzido a partir de operações que se implantam ao sabor das oportunidades, com objetivos especulativos e sem visão sobre os processos destruidores de urbanidade que eles engendram. Trata-se, nesta situação, da prevalência do tempo político sobre o tempo de fabricação da cidade (DESVIGNE, 2011).

A outra região de expansão urbana ocorre na região nordeste da cidade, sob a forma dos loteamentos fechados (ACL-F), e são grandes glebas desconectados da mancha urbana consolidada onde se assentam loteamentos fechados de tamanhos variados. A referência para o desenho desta forma de urbanização está muito mais ligada ao formato das glebas de origem de cada parcelamento do que a uma intenção de continuidade com algum traçado existente ou inserção em um plano de expansão urbana previamente definido. Neste aspecto não ocorrem as conexões com outras malhas preexistentes ou futuras, visto que o loteamento fechado é cercado por muros, e os acessos ocorrem apenas por uma portaria. Por conseguinte, o projeto do loteamento fechado utiliza-se de um sistema viário sinuoso e por ruas terminadas em cul-de-sac, o que cria uma malha fechada. O desenho interno, portanto, está totalmente descolado da vida extramuros, e a relação com a cidade se dá a partir de suas portarias e se apoia em eixos viários construídos a partir dos acessos que se ligam as rodovias.

Os loteamentos fechados produzem uma segmentação ${ }^{7}$ no tecido urbano da cidade de difícil reversão, pois os projetos desenvolvidos não guardam relações diretas com uma proposta de cidade, formando enclaves/barreiras, tendo como proposta atender o interesse de determinadas parcelas da sociedade, que, por intermédio das empresas loteadoras e da incorporação imobiliária, visam o aumento de rendas e lucros através da valorização deste modelo de empreendimento. Utilizam-se ainda da

\footnotetext{
${ }^{6}$ Tratado com espaços isolados, representado pela figura da ocupação individual de cada loteamento, que não surge como parte de um sistema contínuo e que de imediato não estabelece qualquer relação direta como os demais loteamentos do seu entorno, entendido portanto, como "fragmentos resultantes de processos autónomos e com lógicas próprias, incapazes de criar uma unidade reconhecível e legível" (FREITAG apud PORTAS; DOMINGUES; CABRAL, 2011, p. 168).

${ }^{7}$ No sentido de que criam barreiras intransponíveis pela execução dos muros de fechamentos das unidades autônomas.
} 
argumentação de que produzem qualidade de vida, sem se preocupar com os efeitos que este modelo pode causar na forma da cidade, principalmente sobre os aspectos dos espaços extramuros.

A distribuição e localização dos loteamentos aqui estudados representa um fenômeno claro de segregação socioespacial e se constitui em um modo de vida próprio. Nesta situação temos, de um lado, a autossegregação cristalizada pelo modelo dos loteamentos fechados voltados a classe média e alta na região nordeste, representado pela população que pode escolher onde quer morar, devido seu poder aquisitivo, e, de outro, a segregação induzida ${ }^{8}$, representada pelos loteamentos EHIS sob os modelos de condomínio de prédios (conjuntos habitacionais) ou de lotes com casas isoladas, predominando na região sudoeste do município, destinado a uma população cativa dos programas sociais.

Esta reflexão apresenta, portanto, as predominâncias distintas de usos e formas de associação de unidades em função das zonas da cidade e da renda predominante, um processo que origina uma tendência de organização espacial em áreas de "forte homogeneidade social interna e de forte disparidade entre elas" (CASTELLS, 1983).

Portanto, o processo de produção urbana na cidade de Campinas ocorre de forma compartimentada e fragmentada, e isto decorre tanto da produção do espaço através do setor privado como também é reforçada na produção do espaço quando patrocinada pelo investimento público. A fragmentação não é um processo isolado em si, mas se insere em um contexto de transformações mais profundas da sociedade contemporânea.

Este processo de fragmentação gera contrastes sociais presentes nas áreas de estudo, estabelecidos pela presença do movimento de expansão urbana protagonizado por loteamentos fechados de médio e alto padrão, dispondo de infraestrutura de qualidade por vezes superior àquela encontrada na cidade "aberta", em contraposição ao conjunto de loteamentos EHIS de baixo padrão, sem fortes centralidades e distantes do centro de empregos, com infraestrutura bastante precária e população dependente dos serviços públicos, além da deterioração do sítio natural e da qualidade do meio ambiente.

\section{Referências}

BARBUTTI, M. R. Formas da expansão urbana na cidade de Campinas no período de 2000-2017. Campinas: PUC-Campinas, 2019. 183f.: il.

CALDEIRA, T. P. R. Enclaves fortificados: a nova segregação urbana. Novos Estudos - Cebrap, n. 47, pp. 155-176, 1997.

CAMPINAS. Lei Municipal oㅜ 6.031 de 28 de dezembro de 1988.

. Lei Municipal no 8.736 de 9 de janeiro de 1996.

Lei Municipal no 10.410 de 17 de janeiro de 2000. Diário Oficial do Município de Campinas, 18 jan. 2000.

CASTELLS, M. A questão urbana. Rio de Janeiro: Paz e Terra, 1983.

CORRÊA, R. L. Segregação residencial: classes sociais e espaço urbano. VASCONCELOS, P. A.; CORRÊA, R. L.; PINTAUDI, S. M. A cidade contemporânea: segregação espacial. São Paulo: Contexto, 2018.

DESVIGNE, M. Le paysage en prèalable. Marseille: Parentheses, 2011.

FREITAS, E. L. H. Loteamentos fechados. Tese (Doutorado) - Faculdade de Arquitetura e Urbanismo, Universidade de São Paulo, São Paulo, 2008.

\footnotetext{
${ }^{8}$ Segregação induzida, de acordo com Souza (2013, p. 69-70), se dá quando as pessoas não escolhem viver em um determinado local, sendo forçadas a isso. Os pobres são induzidos, por seu baixo poder aquisitivo, a residirem em locais afastados do centro e das eventuais amenidades naturais e/ou desprezados pelos moradores mais abastados.
} 
HARVEY, D. Cidades rebeldes: do direito à cidade à revolução urbana. São Pauo: Martins Fontes, 2014.

LAMAS, J. M. R. G. Morfologia urbana e desenho da cidade. 2. ed. Lisboa: Fundação Calouste Gulbenkian, 2000.

PANERAI, P. Análise urbana. Brasília: Ed. UnB, 2006.

PORTAS, N.; DOMINGUES, A.; CABRAL, J. Políticas urbanas II: transformações, regulação e projetos. Lisboa: Fundação Calouste Gulbenkian, 2011.

SHIMBO, L. Z. Habitação social de mercado: a confluência entre Estado, empresas construtoras e capital financeiro. Belo Horizonte: C/Arte, 2012.

SOJA, E. W. Exópolis: la reestructuración de la forma urbana. In: SOJA, E. W. Postmetrópolis: estudios críticos sobre las ciudades y las regiones. Madrid: Traficantes de Sueños, 2008.

SOUZA, M. L. ABC do desenvolvimento urbano. 7. Ed. Rio de Janeiro: Bertrand Brasil, 2013. 